\title{
Dynamic expression of Endoglin, a TGF- $\beta$ co-receptor, during pre-circulation vascular development in chick
}

\author{
CANTAS ALEV1,2,a, BRENDAN A.S. MCINTYRE1,a,b, KANAKO OTA ${ }^{1}$ and GUOJUN SHENG*,1 \\ ${ }^{1}$ Laboratory for Early Embryogenesis, RIKEN Center for Developmental Biology and \\ ${ }^{2}$ Vascular Regeneration Research Group, Institute of Biomedical Research and Innovation, Kobe, Japan
}

\begin{abstract}
Mutations in the human Endoglin gene, encoding a dimeric TGF- $\beta$ co-receptor, lead to type 1 hereditary hemorrhagic telangiectasia. Studies in mice have revealed important roles of Endoglin in endothelial cell proliferation, differentiation and integrity. Endoglin ${ }^{-/}$- mouse embryos die at mid-gestation due to cardiac defects and vessel rupture. Its role during early vasculogenesis is unclear, as the initial phase of vascular endothelial cell formation appears unaffected in Endoglin $^{-1-}$ embryos. In order to understand possible roles of Endoglin in early vascular development, we used the chick model and analyzed the temporal and spatial expression pattern of Endoglin during vasculogenesis in pre-circulation stage chick embryos. Weak Endoglin expression was detected at $\mathrm{HH} 4$ in the node and in the extraembryonic mesoderm. The node-specific expression is transitory and disappears after HH5. Strong up-regulation of Endoglin expression is seen at $\mathrm{HH8}$ in all endothelial progenitors undergoing morphological changes to become endothelial cells. Most extraembryonic splanchnopleural vascular endothelial cells down-regulate Endoglin after their morphological differentiation, whereas lateral plate and cardiac endothelial cells remain positive until HH12, followed by a clear drop after circulation starts at HH13. Progenitors for the pronephric duct are positive from HH10 to HH12, but down-regulate Endoglin after epithelialization of duct cells. Overall, these data reveal a dynamic expression pattern of Endoglin in pre-circulation chick development and indicate that Endoglin may play an important role in the transition from endothelial progenitors to functional endothelial cells during early vascular development.
\end{abstract}

KEY WORDS: CD105, vasculogenesis, vasculature, endothelial cell, hematopoiesis, progenitor, chicken

\section{Introduction}

Endoglin (also known as CD105) is a co-receptor for the transforming growth factor-beta (TGF- $\beta$ ) superfamily (Goumans and Mummery, 2000; Lebrin and Mummery, 2008; ten Dijke et al., 2008). In mammals, it has been reported to be expressed in active endothelial cells and during early extraembryonic mesoderm differentiation (Ema et al., 2006; Jonker and Arthur, 2002). In chick, embryonic circulation starts at stage Hamburger and Hamilton (HH) 13 (Eichmann etal., 2005; Hamburger and Hamilton, 1992). The expression pattern of Endoglin had been studied in chick with respect to cardiac differentiation (Vincent et al., 1998) and in adult lung and post-circulation yolk sac vasculature (Raab etal., 1999). During post-circulation chick development, Endoglin was also found to be expressed intraembryonically in cardiac endothelium and in developing vessels, and was shown to be involved in the process of epithelial-to-mesenchymal transformation (EMT) during cardiac valve formation (Mercado-Pimentel et al., 2007). The Endoglin ${ }^{-/}$mouse is embryonic lethal with angiogenic defects in addition to vessel rupturing and lack of cardiac EMT by mid-gestation, but with the vasculature appearing normal before E8.5 (Arthur et al., 2000; Bourdeau et al., 1999; Li et al., 1999). Endoglin ${ }^{+-}$mice are viable and have been used to model

Abbreviations used in this paper:EMT, epithelial-mesenchymal transformation; TGF- $\beta$, transforming growth factor beta.

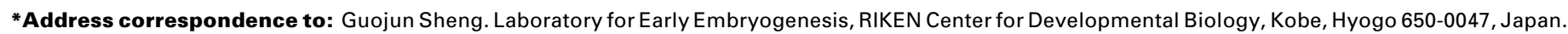
Fax: +81-78-306-3146. e-mail: sheng@cdb.riken.jp

a Note: These authors contributed equally to this work.

b Current Address: Physiology and Experimental Medicine Program, The Hospital for Sick Children, Toronto, Ontario, Canada
} 
hereditary hemorrhagic telangiectasia type 1 (HHT1; MIM\#187300) (ten Dijke et al., 2008), a condition observed in humans with mutations in the Endoglin gene resulting in haploinsufficiency (Abdalla and Letarte, 2006). Although not normally lethal, patients with HHT1 suffer from chronic nosebleeds (epistaxis), telangiectases, have high incidence of pulmonary and cerebral arteriovenous malformations and appear to be predisposed to developing pulmonary arterial hypertension (Lenato and Guanti, 2006), all of which underscore the important underlying function of Endoglinin the establishment and maintenance of the circulatory system.

Furthermore, it has been suggested that Endoglin is involved in early hematopoietic development, with Endoglin being expressed in mouse embryonic stem cell (mESC)-derived mesodermal FLK1 + precursors (Cho et al., 2001) and blast colony-forming cells (BL-CFCs) (Perlingeiro, 2007). In vitrodifferentiation assays showed that Endoglim/- mESCs have reduced myelopoiesis and erythropoiesis, whereas the formation of lymphoid and vascular precursors appeared unaffected (Cho et al., 2001). Anemia observed in patients with $\mathrm{HHT} 1$ and in Endoglin ${ }^{\prime-}$ mice is another indicator for a possible role of Endoglin in erythropoiesis. In the adult setting, in addition to its involvement in angiogenesis and vascular repair (Hayrabedyan etal., 2005; van Laake etal., 2006), Endoglin is expressed in long-term repopulating hematopoietic stem cells from bone marrow (Chen et al., 2002) and was reported to play a role in erythroid lineage differentiation (Moody et al., 2007). Increased levels of Endoglin expression were also found in tumors (Fonsatti et al., 2001), atherosclerotic plaques (Conley et al., 2000) and during inflammation and wound healing (Torsney et al., 2002). Endoglin expression is thus closely correlated with neo-vascular formation and may play a role in the pathogenesis of vascular diseases. However, in vitro angioblast differentiation from Endoglin ${ }^{-}$mESCs was reported to be unaffected (Perlingeiro, 2007) and the primary endothelial network in Endoglin ${ }^{--}$mouse embryos appears normal (Li et al., 1999), indicating that Endoglin may be dispensable for early vascular formation.

\section{Results and Discussion}

The chick Endoglin gene (AY702002) encodes a 644 amino acid polypeptide, with an overall $34 \%$ identity to the human LEndoglin protein. Searches of EST databases did not indicate the existence of the alternatively spliced S-Endoglin in chick, an isoform up-regulated in senescent endothelial cells in mammals (Bellon etal., 1993; Blanco et al., 2008; Perez-Gomez et al., 2005; Velasco et al., 2008). A high degree of identity between chick and mammalian Endoglins was found in the transmembrane and short cytoplasmic tail domains, with $100 \%$ conservation in the last 24 amino acid residues containing the sites that are known to be phosphorylated by activated T $\beta$ RII, Alk1 and Alk5 and a PDZ motif (Koleva et al., 2006). Its expression pattern in the extraembryonic regions and in pre-circulation development has not been examined. We generated an anti-sense probe corresponding to amino acid residues 111-304 of the full length chick Endoglin (see Materials and Methods), and performed whole-mount in situ hybridization on embryos from stage $\mathrm{HH}$, when blood/endothelial progenitors start to be generated from the posterior primitive streak (Jaffredo et al., 2005; Nakazawa et al., 2006; Shin et al., 2009), to $\mathrm{HH} 13$, when circulation is initiated.

At $\mathrm{HH} 4$, the earliest time point examined, weak Endoglin expression was observed in the Hensen's node and the head process (Fig.1A; arrowhead). This is transitory, as no Endoglin
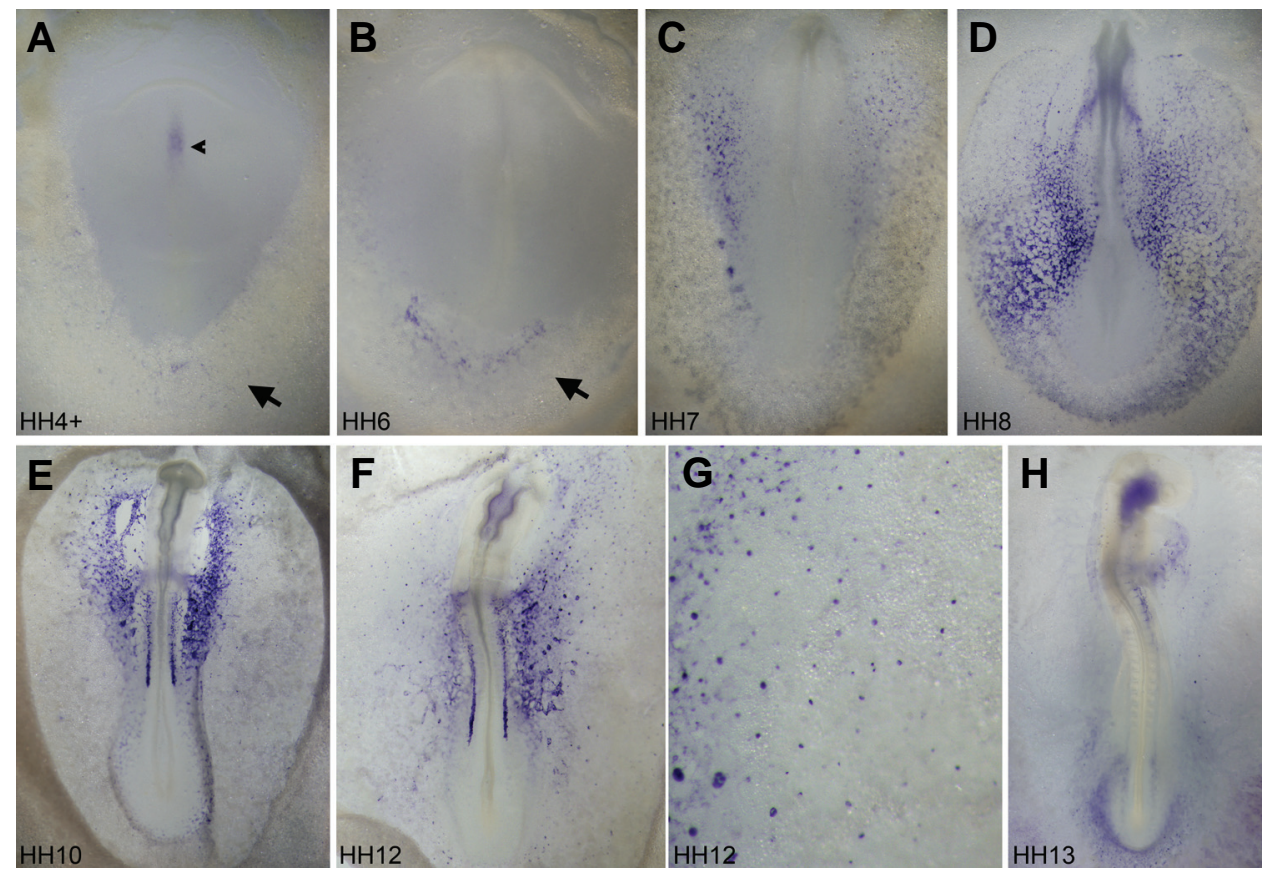

Fig. 1. Whole-mount in situ hybridization analysis of Endoglin from stage $\mathrm{HH} 4$ to stage HH13. (A) At HH4+, Endoglin is expressed very weakly in the Hensen's node and head process (arrowhead) and in the newly formed extraembryonic mesoderm (arrow). (B) At HH6, expression in the node and node-derived tissues is not detected. Broader, yet still very weak, Endoglin expression is observed in the extraembryonic mesoderm (arrow). (C) By HH7, expression in the area vasculosa becomes stronger, especially in the future medial extraembryonic and lateral plate regions. (D) At HH8, robust expression is observed throughout extraembryonic and intraembryonic vasculature. (E) By HH10, extraembryonic vascular expression is reduced significantly, with intraembryonic vasculature (including cardiac and lateral plate vessels) strongly positive for Endoglin. Progenitors for the pronephric duct are also strongly positive. (F) At HH12, vascular expression of Endoglin is further reduced, with strong positive cells confined to mid-level medial splanchnopleural vasculature. Pronephric duct progenitors remain strongly positive. Somatopleural vessels are undergoing active vasculogenesis, marked by strong expression of Endoglin in numerous small clusters in both extra- and intra-embryonic regions. (G) Magnified view of the extraembryonic somatopleural Endoglin positive clusters at HH12. (H) By HH13, Endoglin expression is much reduced throughout the entire developing embryo. Weak expression is still detected in the heart and the posterior part of the embryo, where new vessels continue to be formed. 
expression was detected in the node or node-derived tissues at later stages. Weak expression could also be observed at this stage in the extraembryonic-fated mesoderm territory (Figs. 1A, $2 \mathrm{~A}$; arrows). The extraembryonic mesoderm at this stage strongly expresses hemangioblast, hematopoietic and endothelial precursor markers such as Gata2, Scl, Lmo2, Ets1 and Vegfr2 (Bollerot et al., 2005; Minko et al., 2003; Nakazawa et al., 2006; Shin et al., 2009), indicating that Endoglinexpression does correlate with the initial steps of endothelial precursor specification.

$\mathrm{By} \mathrm{HH} 5$ and $\mathrm{HH} 6$, Endoglin expression in the extraembryonic mesoderm covers a slightly wider area, but remains weak (Fig. $1 \mathrm{~B}$; arrow). Stronger and wider expression was observed at $\mathrm{HH} 7$ (Fig. 1C). The extraembryonic mesoderm at this stage starts to be segregated morphologically into three cell lineages: the blood, endothelial and smooth muscle cells (Shin et al., 2009). The first two cell lineages come from blood island aggregates and it is at $\mathrm{HH} 7$ when hemoglobin gene expression, a marker for terminal differentiation of blood cells, starts to be seen in scattered cells within the blood island population (Alev et al., 2008; Nagai and Sheng, 2007; Nakazawa et al., 2009; Nakazawa et al., 2006; Weng et al., 2007). Endoglin up-regulation at $\mathrm{HH} 7$ thus seems to mark the initiation of the morphological differentiation of endothelial fated cells. In blood islands located more medially in the embryo, Endoglin expression was seen in most cells (Fig. 2B; right arrow), correlating with the fact that most of medially located blood islands contribute only to endothelial cells (Nakazawa etal.,
2006). More laterally located blood islands have less Endoglin positive cells (Fig. 2B; middle and left arrows; Fig. 2 C,D) and in most cases these positive cells are located at the periphery and on one side of a blood island cluster (Fig. 2D).

At HH8, Endoglin expression becomes very robust (Fig. 1D). Strong expression was detected in all endothelial precursors in the process of undergoing morphological changes to become endothelial cells, including endocardial progenitors (Fig. 2E), dorsal aorta progenitors (Fig. 2F) and all other splanchnopleuralassociated vessel progenitors in both non-hemogenic (Fig. 2F) and hemogenic (Fig. 2 G,H) regions. Newly formed vascular endothelial cells are also positive for Endoglin(Fig. 2I). Morphological differentiation of endothelial progenitor cells and formation of the vascular plexus take place actively at $\mathrm{HH} 8$ and HH9. Most vascular endothelial cells down-regulate Endoglin expression soon after their morphological differentiation, and by $\mathrm{HH} 10$ (Fig. $1 \mathrm{E})$, strong Endoglin expression was only seen in more medially located fusing endocardia (Fig.3 A,B) and lateral plate vessel cells (Fig. 3C), whereas extraembryonic vessels do not express Endoglin at all by this stage (Fig. 3E). Small cell clusters located in the somatopleure express Endoglin strongly (Fig. 3D). These cells, similar to blood island aggregates in the splanchnopleure (our unpublished data), have a slightly delayed differentiation program and Endoglin positive cells there will differentiate into small somatopleural vessels (Fig. 3K).

Circulation in chick embryos starts at about $\mathrm{HH} 12$ to $\mathrm{HH} 13$.

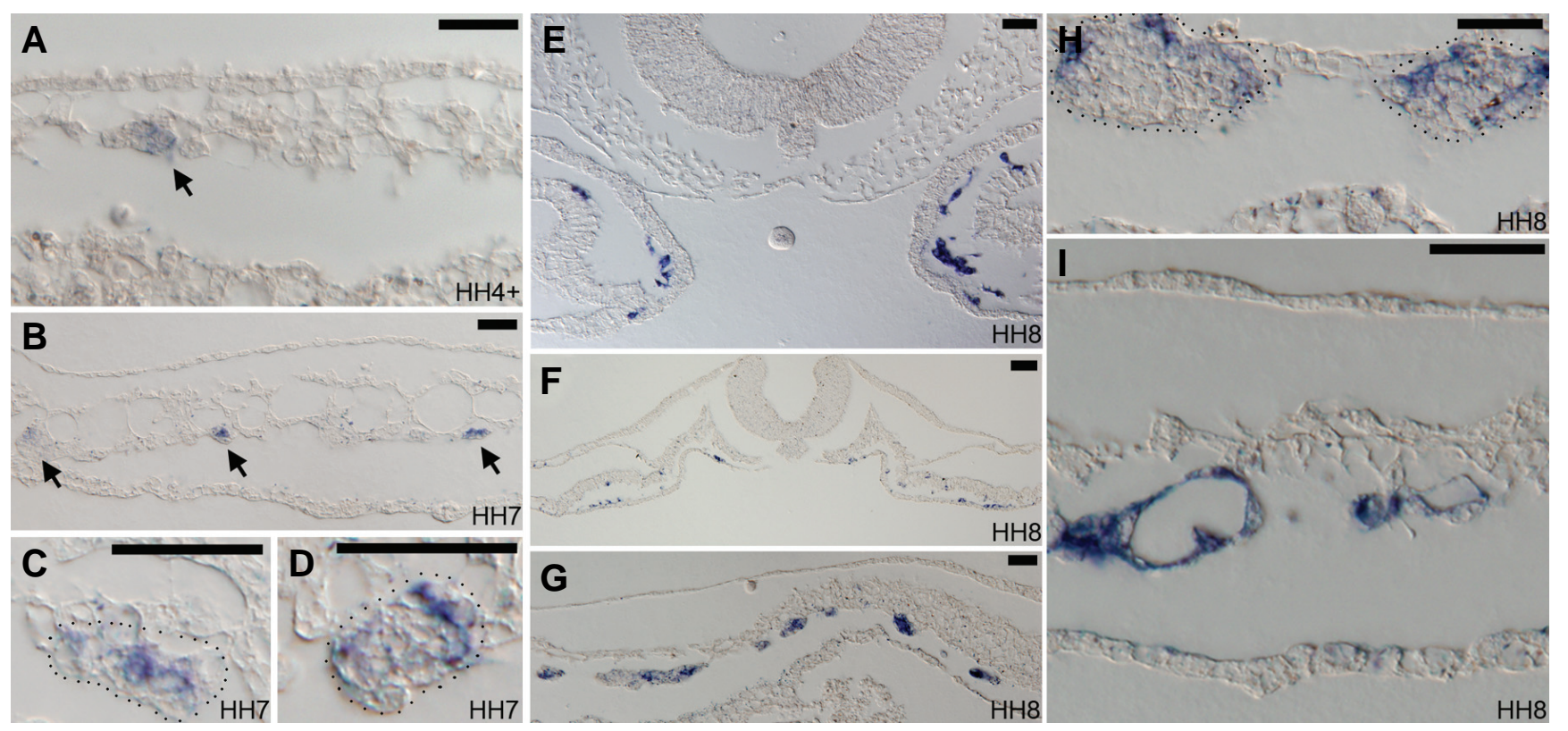

Fig. 2. Paraffin sections of Endoglin expressing embryos from HH4 to HH8. (A) Section through posterior region of the HH4+ embryo shown in Fig. 1A. Arrow indicates very weak expression of Endoglin in a small number of extraembryonic mesoderm cells. (B-D) Sections through the posterior part of the HH7 embryo in Fig. 1C. Arrows in (B) indicate that some cells within forming blood island clusters are positive for Endoglin. (C,D) Magnified views of lateral blood island cluster (marked by dotted lines), with some cells in the cluster positive for Endoglin. Blood island clusters in this region normally give rise to both blood cells and endothelial cells, whereas blood islands in more medial regions give rise only to endothelial cells. In these lateral blood island clusters, most Endoglin positive cells are located in the periphery of the cluster as shown in (D). Some are located within the cluster. (E-F) Sections of the HH8 embryo in Fig.1D. (E) A section through the cardiogenic region, with endocardial precursors strongly positive for Endoglin. (F) A section through mid-level of the embryo, with all embryonic endothelial progenitors positive for Endoglin. (G) A section through the extraembryonic region, with medially located blood islands having most of their constituent cells positive for Endoglin and laterally located blood islands having a few positive cells. (H) A magnified view of lateral extraembryonic blood islands, showing peripheral locations of Endoglin positive cells within blood islands (dotted lines). (I) In many lateral plate vessels, strong Endoglin positive signals remain in morphologically differentiated endothelial cells. Scale bar in all panels: $50 \mu \mathrm{m}$. 


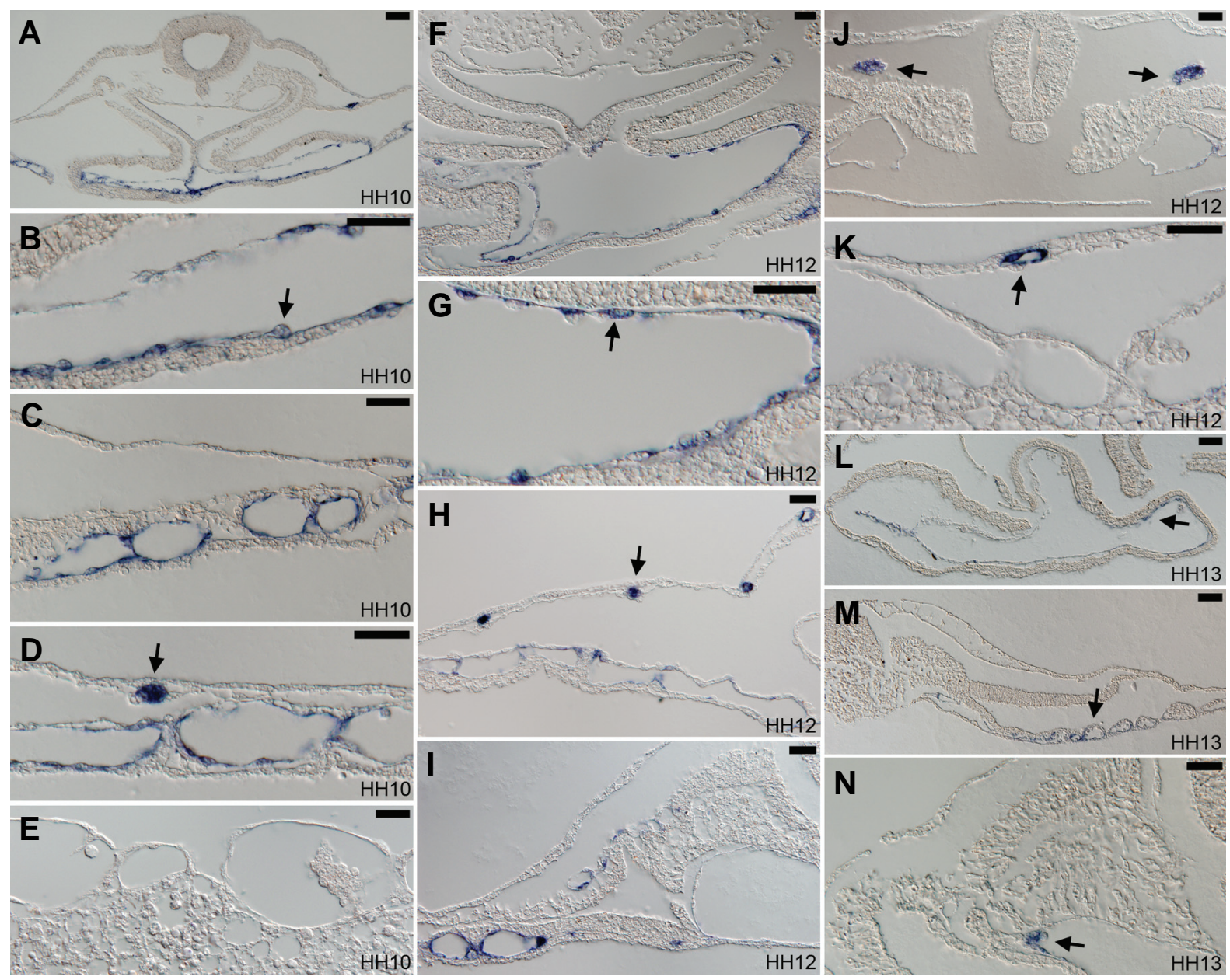

Fig. 3. Paraffin sections of Endoglin expressing embryos from HH10 to HH13. (A-E) Sections of the HH10 embryo shown in Fig.1E. (A) Fusing endocardia are strongly positive for Endoglin (magnified in (B), with arrow indicating a positive endocardial cell). (C) Lateral plate splanchnopleural vessels remain positive for Endoglin. (D) In lateral plate and extraembryonic regions, somatopleural vessel precursors are strongly positive for Endoglin (arrow). (E) Lateral extraembryonic vessels are negative for Endoglin. Blood cells and blood precursors are always negative for Endoglin. (F-K) Sections of the HH12 embryo shown in Fig. 1F. (F) Fused endocardium remains positive for Endoglin (magnified view in (G), with arrow indicating a positive endocardial cell). (H) Somatopleural vessel precursors are strongly positive for Endoglin (arrow), whereas splanchnopleural vessels have much reduced expression. (I) Only in the mid-level of the embryo Endoglin in splanchnopleural vessels persists. (J) Developing pronephric duct progenitors (arrows) are strongly positive for Endoglin. (K) Somatopleural vessels (arrow) remain positive for a short period of time after their formation. (L-N) Sections of the HH13 embryo shown in Fig. $1 \mathrm{H}$. (L) The endocardium remains weakly positive for Endoglin in some cells (arrow). (M) Newly developed vessels in the posterior part of the embryo are weakly positive for Endoglin. (N) A few cells in the aortic branch in contact with the forming pronephron express Endoglin. Scale bar in all panels: $50 \mu \mathrm{m}$.

Endoglin expression levels drop in most vessels at peri-circulation stages (Fig. $1 \mathrm{~F}, \mathrm{H}$ ). In the endocardium, expression is prominent at HH12 (Fig. $3 F, G)$, but decreases significantly, although still detectable, at $\mathrm{HH} 13$ (Fig. 3L). A similar drop was seen in lateral plate vessels (Fig. $3 \mathrm{H}, \mathrm{I}, \mathrm{M})$. Endoglin expression in small cell clusters in the somatopleure is still strong at HH12 (Fig.1G; arrows in Fig. $3 \mathrm{H}, \mathrm{K}$ ), but disappears at $\mathrm{HH} 13$ (Fig. $1 \mathrm{H}$ ). At HH13, weak Endoglin signals were detected in the contact region between the dorsal aorta and the developing pronephric duct and tubule (Fig. $3 \mathrm{~N}$ ), possibly representing the aortic branch of the developing external glomerulus (Hiruma and Nakamura, 2003). From $\mathrm{HH} 10$ to $\mathrm{HH} 12$, the precursors for the pronephric duct are strongly positive for Endoglin (Figs.1E,F, 3J). This and the node cells at $\mathrm{HH} 4$ are the only two non-endothelial cell types found to express Endoglin in our study.
In summary, we report here that the expression of Endoglin during embryonic pre-circulation stages in the chick is mainly confined to areas of vasculogenesis, being strongest in endothelial cells undergoing active vascularization and lower or undetectable in differentiated vessels. At all stages examined here, vascular smooth muscle cells and their progenitors do not express Endoglin. Our observations support the idea, as proposed in several mouse studies (Carvalho et al., 2004; Ema et al., 2006; Jonker and Arthur, 2002), that Endoglin plays an important role during vasculogenesis. In chick, however, Endoglin does not appear to be involved in early hemangioblast (common blood and endothelial progenitor) specification or hematopoietic development. During the differentiation of endothelial progenitors, Endoglin expression seems to correlate best with the phase of morphological changes required for the formation of functional vessel cells, 
and less well with the specification of endothelial progenitor cells or the maintenance of vascular morphology or integrity after their formation. In formed vascular structures undergoing active remodeling, such as in the endocardium and lateral plate splanchnopleural vessels, Endoglinexpression is maintained for a short while after initial morphological differentiation. It is therefore possible that the Endoglin mediated TGF- $\beta$ signaling cascade regulates the molecular cues involved in the terminal fate choice of endothelial progenitors to adopt a differentiated endothelial morphology via the initiation of synthesis of intracellular and extracellular molecular components unique for functional endothelial cells (e.g., endothelial specific cell-cell junctional and extracellular matrix proteins). During chick early development, Endoglinis in our opinion the best molecular marker yet described for the initiation of terminal differentiation of endothelial progenitor cells.

\section{Materials and Methods}

Fertilized Gallus gallus domesticus eggs were purchased from Shiroyama Farm (Kanagawa, Japan) and incubated to desired stages at $38.5^{\circ} \mathrm{C}$. The DNA fragment for generating Endoglin in situ probe was amplified by PCR from stage $\mathrm{HH} 12$ cDNA preparation with the following two primers: 5'-AGAACCTCCTCATCCACACT-3' and 5'GCGATGATGCTGTAGTTCTT-3'. The amplified fragment was confirmed by sequencing and corresponds to nucleotides 332-911 of NCBI \#NM_001080887. Whole-mount in situ analysis was carried out as previously described (Nakazawa et al., 2006). All in situ hybridization experiments were performed at least in triplicate for each stage described. Stained embryos were photographed with an Olympus SZX12 microscope using a DP70 camera, followed by paraffin-embedded sectioning $(10 \mu \mathrm{m})$. Sections were photographed with an Olympus BX51 microscope. All panels in Figure 1 have stained embryos oriented with the rostral side up and viewed from the ectoderm side. All section panels in Figures 2 and 3 are oriented with the ectoderm side up.

\section{Acknowledgements}

The authors would like to thank Dr. Michelle Letarte and Dr. Mira Puri for helpful discussions.

\section{References}

ABDALLA, S.A. and LETARTE, M. (2006). Hereditary haemorrhagic telangiectasia: current views on genetics and mechanisms of disease. JMed Genet43: 97-110.

ALEV, C., MCINTYRE, B.A., NAGAI, H., SHIN, M., SHINMYOZU, K., JAKT, L.M. and SHENG, G. (2008). BetaA, the major beta globin in definitive red blood cells, is present from the onset of primitive erythropoiesis in chicken. Dev Dyn 237: 1193-1197.

ARTHUR, H.M., URE, J., SMITH, A.J., RENFORTH, G., WILSON, D.I., TORSNEY, E., CHARLTON, R., PARUMS, D.V., JOWETT, T., MARCHUK, D.A. et al. (2000). Endoglin, an ancillary TGFbeta receptor, is required for extraembryonic angiogenesis and plays a key role in heart development. Dev Bio/217: 42-53.

BELLON, T., CORBI, A., LASTRES, P., CALES, C., CEBRIAN, M., VERA, S., CHEIFETZ, S., MASSAGUE, J., LETARTE, M. and BERNABEU, C. (1993). Identification and expression of two forms of the human transforming growth factor-beta-binding protein endoglin with distinct cytoplasmic regions. Eur $J$ Immuno/23: 2340-2345.

BLANCO, F.J., GRANDE, M.T., LANGA, C., OUJO, B., VELASCO, S., RODRIGUEZBARBERO, A., PEREZ-GOMEZ, E., QUINTANILLA, M., LOPEZ-NOVOA, J.M. and BERNABEU, C. (2008). S-endoglin expression is induced in senescent endothelial cells and contributes to vascular pathology. Circ Res 103: 13831392.

BOLLEROT, K., ROMERO, S., DUNON, D. and JAFFREDO, T. (2005). Core binding factor in the early avian embryo: cloning of Cbfbeta and combinatorial expression patterns with Runx1. Gene Expr Patterns 6: 29-39.

BOURDEAU, A., DUMONT, D.J. and LETARTE, M. (1999). A murine model of hereditary hemorrhagic telangiectasia. J Clin Invest 104: 1343-1351.

CHEN, C.Z., LI, M., DE GRAAF, D., MONTI, S., GOTTGENS, B., SANCHEZ, M.J., LANDER, E.S., GOLUB, T.R., GREEN, A.R. and LODISH, H.F. (2002). Identification of endoglin as a functional marker that defines long-term repopulating hematopoietic stem cells. Proc Natl Acad Sci USA 99: 15468-15473.

CHO, S.K., BOURDEAU, A., LETARTE, M. and ZUNIGA-PFLUCKER, J.C. (2001) Expression and function of CD105 during the onset of hematopoiesis from Flk1(+) precursors. Blood98: 3635-3642.

CONLEY, B.A., SMITH, J.D., GUERRERO-ESTEO, M., BERNABEU, C. and VARY, C.P. (2000). Endoglin, a TGF-beta receptor-associated protein, is expressed by smooth muscle cells in human atherosclerotic plaques. Atherosclerosis 153: 323-335.

EICHMANN, A., YUAN, L., MOYON, D., LENOBLE, F., PARDANAUD, L. and BREANT, C. (2005). Vascular development: from precursor cells to branched arterial and venous networks. Int J Dev Bio/49: 259-267.

EMA, M., YOKOMIZO, T., WAKAMATSU, A., TERUNUMA, T., YAMAMOTO, M. and TAKAHASHI, S. (2006). Primitive erythropoiesis from mesodermal precursors expressing VE-cadherin, PECAM-1, Tie2, endoglin, and CD34 in the mouse embryo. Blood 108: 4018-4024.

FONSATTI, E., DEL VECCHIO, L., ALTOMONTE, M., SIGALOTTI, L., NICOTRA, M.R., CORAL, S., NATALI, P.G. and MAIO, M. (2001). Endoglin: An accessory component of the TGF-beta-binding receptor-complex with diagnostic, prognostic, and bioimmunotherapeutic potential in human malignancies. $J \mathrm{Ce} / \mathrm{J}$ Physio/188: 1-7.

GOUMANS, M.J. and MUMMERY, C. (2000). Functional analysis of the TGFbeta receptor/Smad pathway through gene ablation in mice. Int J Dev Bio/44: 253265.

HAMBURGER, V. and HAMILTON, H.L. (1992). A series of normal stages in the development of the chick embryo. 1951. Dev Dyn 195: 231-272.

HAYRABEDYAN, S., KYURKCHIEV, S. and KEHAYOV, I. (2005). Endoglin (cd105) and $\mathrm{S} 100 \mathrm{~A} 13$ as markers of active angiogenesis in endometriosis. Reprod Biol 5: 51-67.

JAFFREDO, T., BOLLEROT, K., SUGIYAMA, D., GAUTIER, R. and DREVON, C. (2005). Tracing the hemangioblast during embryogenesis: developmental relationships between endothelial and hematopoietic cells. Int J Dev Bio/49: 269277.

JONKER, L. and ARTHUR, H.M. (2002). Endoglin expression in early development is associated with vasculogenesis and angiogenesis. Mech Dev110: 193-196.

KOLEVA, R.I., CONLEY, B.A., ROMERO, D., RILEY, K.S., MARTO, J.A., LUX, A and VARY, C.P. (2006). Endoglin structure and function: Determinants of endoglin phosphorylation by transforming growth factor-beta receptors. J Biol Chem 281: 25110-25123.

LEBRIN, F. and MUMMERY, C.L. (2008). Endoglin-mediated vascular remodeling mechanisms underlying hereditary hemorrhagic telangiectasia. Trends Cardiovasc Med 18: 25-32.

LENATO, G.M. and GUANTI, G. (2006). Hereditary Haemorrhagic Telangiectasia (HHT): genetic and molecular aspects. Curr Pharm Des 12: 1173-1193.

LI, D.Y., SORENSEN, L.K., BROOKE, B.S., URNESS, L.D., DAVIS, E.C., TAYLOR, D.G., BOAK, B.B. and WENDEL, D.P. (1999). Defective angiogenesis in mice lacking endoglin. Science 284: 1534-1537.

MERCADO-PIMENTEL, M.E., HUBBARD, A.D. and RUNYAN, R.B. (2007). Endoglin and Alk5 regulate epithelial-mesenchymal transformation during cardiac valve formation. Dev Bio/304: 420-432.

MINKO, K., BOLLEROT, K., DREVON, C., HALLAIS, M.F. and JAFFREDO, T. (2003). From mesoderm to blood islands: patterns of key molecules during yolk sac erythropoiesis. Gene Expr Patterns 3: 261-272.

MOODY, J.L., SINGBRANT, S., KARLSSON, G., BLANK, U., ASPLING, M. FLYGARE, J., BRYDER, D. and KARLSSON, S. (2007). Endoglin is not critical for hematopoietic stem cell engraftment and reconstitution but regulates adult erythroid development. Stem Cel/s 25: 2809-2819.

NAGAI, H. and SHENG, G. (2007). Cis-cotranscription of two beta globin genes during chicken primitive hematopoiesis. PLOS ONE2: e703. 
NAKAZAWA, F., ALEV, C., SHIN, M., NAKAYA, Y., JAKT, L.M. and SHENG, G. (2009). PBRL, a putative peripheral benzodiazepine receptor, in primitive erythropoiesis. Gene Expr Patterns 9: 114-121.

NAKAZAWA, F., NAGAI, H., SHIN, M. and SHENG, G. (2006). Negative regulation of primitive hematopoiesis by the FGF signaling pathway. Blood 108: 33353343

PEREZ-GOMEZ, E., ELENO, N., LOPEZ-NOVOA, J.M., RAMIREZ, J.R., VELASCO, B., LETARTE, M., BERNABEU, C. and QUINTANILLA, M. (2005). Characterization of murine S-endoglin isoform and its effects on tumor development. Oncogene 24: 4450-4461.

PERLINGEIRO, R.C. (2007). Endoglin is required for hemangioblast and early hematopoietic development. Development 134: 3041-3048.

RAAB, U., LASTRES, P., AREVALO, M.A., LOPEZ-NOVOA, J.M., CABANAS, C., DE LA ROSA, E.J. and BERNABEU, C. (1999). Endoglin is expressed in the chicken vasculature and is involved in angiogenesis. FEBS Lett459: 249-254.

SHIN, M., NAGAI, H. and SHENG, G. (2009). Notch mediates Wnt and BMP signals in the early separation of smooth muscle progenitors and blood/endothelial common progenitors. Development 136: 595-603.
TEN DIJKE, P., GOUMANS, M.J. and PARDALI, E. (2008). Endoglin in angiogenesis and vascular diseases. Angiogenesis 11: 79-89.

TORSNEY, E., CHARLTON, R., PARUMS, D., COLLIS, M. and ARTHUR, H.M. (2002). Inducible expression of human endoglin during inflammation and wound healing in vivo. Inflamm Res 51: 464-470.

VAN LAAKE, L.W., VAN DEN DRIESCHE, S., POST, S., FEIJEN, A., JANSEN M.A., DRIESSENS, M.H., MAGER, J.J., SNIJDER, R.J., WESTERMANN, C.J., DOEVENDANS, P.A. et al. (2006). Endoglin has a crucial role in blood cellmediated vascular repair. Circulation 114: 2288-2297.

VELASCO, S., ALVAREZ-MUNOZ, P., PERICACHO, M., DIJKE, P.T., BERNABEU, C., LOPEZ-NOVOA, J.M. and RODRIGUEZ-BARBERO, A. (2008). L- and Sendoglin differentially modulate TGFbeta1 signaling mediated by ALK1 and ALK5 in L6E9 myoblasts. J Cel/ Sci121: 913-919.

VINCENT, E.B., RUNYAN, R.B. and WEEKS, D.L. (1998). Production of the transforming growth factor-beta binding protein endoglin is regulated during chick heart development. Dev Dyn 213: 237-247.

WENG, W., SUKOWATI, E.W. and SHENG, G. (2007). On hemangioblasts in chicken. PLOS ONE2: e1228.

\section{Further Related Reading, published previously in the Int. J. Dev. Biol.}

See Special Issue Pattern Formation edited by Michael K. Richardson and Cheng-Ming Chuong at: http://www.ijdb.ehu.es/web/contents.php?vol=53\&issue=5-6

Insulin-like growth factor-2 regulates early neural and cardiovascular system development in zebrafish embryos

Lori Hartnett, Catherine Glynn, Catherine M. Nolan, Maura Grealy and Lucy Byrnes Int. J. Dev. Biol. (2010) 54: 573-583 (doi: 10.1387/ijdb.092922lh)

Epithelial-Mesenchymal Transitions in development and disease: old views and new perspectives

M. Angela Nieto

Int. J. Dev. Biol. (2009) 53: 1541-1547

A novel role of the glial fate determinant glial cells missing in hematopoiesis Cécile Jacques, Laurent Soustelle, István Nagy, Céline Diebold and Angela Giangrande Int. J. Dev. Biol. (2009) 53: 1013-1022

Developmentally regulated expression of hemoglobin subunits in avascular tissues Fiona C. Mansergh, Susan M. Hunter, Jenny C. Geatrell, Miguel Jarrin, Kate Powell, Martin J. Evans and Michael A. Wride Int. J. Dev. Biol. (2008) 52: 873-886

Vasculogenesis and angiogenesis in the mouse embryo studied using quail/mouse chimeras

Michel Pudliszewski and Luc Pardanaud

Int. J. Dev. Biol. (2005) 49: 355-361

Vascular development: from precursor cells to branched arterial and venous networks Anne Eichmann, Li Yuan, Delphine Moyon, Ferdinand leNoble, Luc Pardanaud and Christiane Bréant

Int. J. Dev. Biol. (2005) 49: 259-267

Development and pathology of the hyaloid, choroidal and retinal vasculature Magali Saint-Geniez and Patricia A. D'Amore

Int. J. Dev. Biol. (2004) 48: 1045-1058

The contribution of the proepicardium to avian cardiovascular development JM Perez-Pomares, A Phelps, R Munoz-Chapuli, A Wessels Int. J. Dev. Biol. (2001) 45: S155-S156

Functional analysis of the TGFbeta receptor/Smad pathway through gene ablation in mice

M J Goumans and C Mummery

Int. J. Dev. Biol. (2000) 44: 253-265

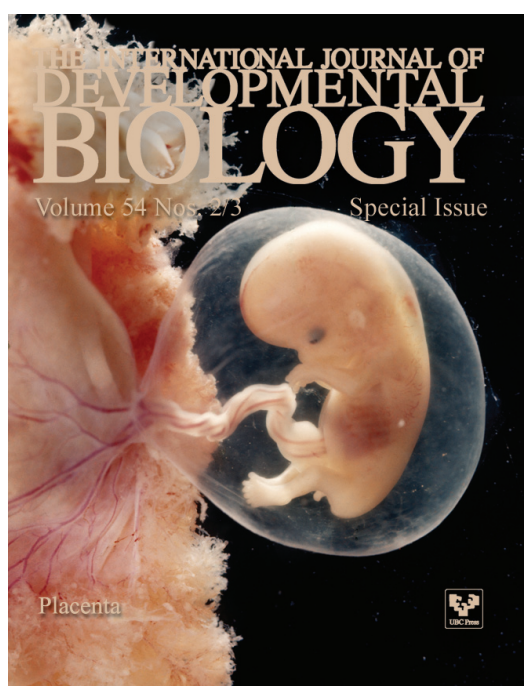

5 yr ISI Impact Factor $(2008)=3.271$

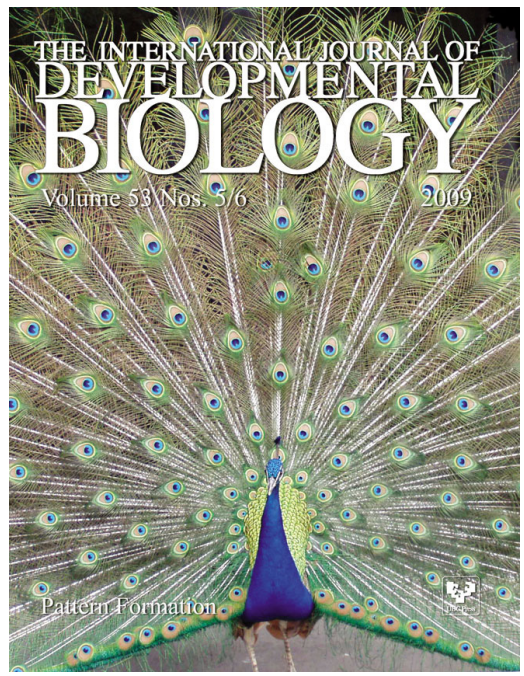

